\title{
Transient Catalytic Activity of Calcined Dolomitic Limestone in Fluidized Bed during Gasification of Woody Biomass.
}

\author{
M. Pohořelýa ${ }^{\mathrm{a}, \mathrm{b}}$, M. Jeremiáš ${ }^{* *}$, S. Skoblia ${ }^{\mathrm{d}}$, Z. Beňo ${ }^{\mathrm{d}}$, M. Šyc ${ }^{\mathrm{a}}$, K. Svoboda ${ }^{\mathrm{a}, \mathrm{e}}$ \\ a Institute of Chemical Process Fundamentals, Academy of Science of the Czech
} Republic, Rozvojová 135, 16502 Praha 6-Suchdol, Czech Republic.

${ }^{b}$ Department of Power Engineering, University of Chemistry and Technology in Prague, Technická 5, 16628 Praha 6, Czech Republic.

${ }^{\mathrm{c}}$ Combustion and CCS Centre, SWEE, Cranfield University, Cranfield, Bedfordshire, MK43 0AL, UK.

${ }^{\mathrm{d}}$ Department of Gas, Coke and Air Protection, University of Chemistry and Technology in Prague, Technická 5, 16628 Praha 6, Czech Republic.

${ }^{\mathrm{e}}$ Faculty of the Environment, University of Jan Evangelista Purkyně, Králova Výšina 7, 40096 Ústí nad Labem, Czech Republic.

\begin{abstract}
Calcined dolomitic limestone mixed with silica sand in a fluidized bed can catalytically enhance the gasification of woody biomass. The lime is prone to attrition and carry-over from the reactor and to deactivation caused by pore sintering; therefore, it has to be replenished continuously or periodically to maintain catalytic activity of the fluidized bed. The main aim of this paper was to explore the level of the decrease of the catalytic activity of the fluidized bed if the limestone is not replenished and to estimate a critical period for its top-up.
\end{abstract}

Wood chips were gasified first in a silica sand fluidized bed (1080g), to obtain background data without the catalytic effect of limestone. After 5 hours of operation, dolomitic limestone (1050 g) was added to the fluidized bed and let calcine. Its catalytic activity was monitored during the following 6 hours.

\footnotetext{
*Corresponding author. E-mail address: michal.jeremias@me.com (M. Jeremiáš) 
During the second part of the experiment, the yield of the main gases $\left(\mathrm{H}_{2}, \mathrm{CO}, \mathrm{CH}_{4}\right.$, $\mathrm{CO}_{2}$ and $\mathrm{H}_{2} \mathrm{O}$ ) remained almost unchanged. The yield of minor organic gases and tars rose slightly, but still remained far below the value attained with only silica sand. The heavy polyaromatic tar compounds, were effectively decomposed during the first three hours after the addition of dolomitic limestone. It was concluded, that the catalytic activity of dolomitic lime remains in acceptable level during the first three hours after its addition into the fluidized bed, suggesting that periodic rather than continuous replenishment of limestone should be sufficient.

Keywords: Fluidized Bed; Catalyst; Attrition; Tar; Dolomite; Limestone

\section{Introduction}

It is advantageous to convert a solid low-grade fuel into a calorific gas. Gaseous fuel can be used for combined heat and power (CHP) generation with high power production efficiency ${ }^{1,2}$ or (if sufficiently cleaned) can be converted into chemicals with high added value, such as second-generation transport fuels ${ }^{3,4}$.

The conversion can be achieved by pyrolysis (i.e., by heating the solid fuel up to a temperature where it decomposes to char and a vaporized gas fraction), followed by the introduction of a gasifying agent (air or mixtures of $\mathrm{O}_{2}, \mathrm{H}_{2} \mathrm{O}^{5}$ and $\mathrm{CO}_{2}{ }^{6}$ ) and by increasing the temperature $\left(>600^{\circ} \mathrm{C}\right)$.

The pyrolysis and gasifying reactions can occur in different vessels, such as in 'twostage gasifiers' ${ }^{1,7}$ or in different areas within one reactor, such as in fixed-bed reactors. In fluidized bed reactors (FBRs), pyrolysis, combustion and gasification are carried out all in one vessel because of the mixing of the fluidized bed. 
FBRs have the advantage that a catalytic or sorbent material can be deployed directly in the bed, which can improve the gas properties and simultaneously prevent ash sintering and agglomeration of the bed material. The use of catalytically active materials during gasification promotes char conversion, changes product gas composition and reduces tar yield ${ }^{8}$. The selection criteria for the ideal primary gasification catalyst are as follows: (a) good activity in the conversion of tars into gaseous products, efficient in environments containing high concentrations of $\mathrm{H}_{2}, \mathrm{CO}, \mathrm{CO}_{2}, \mathrm{H}_{2} \mathrm{O}$ within the temperature range $700-900{ }^{\circ} \mathrm{C} ;(b)$ good activity in methane reforming reactions; $(c)$ good stability with regard to deactivation through coking, poisoning or sintering; $(d)$ easy regeneration; $(e)$ good resistance to attrition; $(f)$ availability at low cost; and $(g)$ no environmental toxicity, given the significant catalyst mass losses generally measured in fluidized bed reactors. Many catalysts for biomass gasification for direct use in fluidized beds are well described elsewhere ${ }^{9-13}$.

Carbonate materials, especially limestones, satisfy the criteria $a-c, f$ and $g$. They are non-toxic and widely available at low cost for industrial applications. Their catalytic activity in the gasification process is well demonstrated ${ }^{10,14,15}$. However, a significant problem with the use of their calcines lies in their possible friability/fragility. Their particles are typically quite soft and tend to fracture and can disintegrate into dust and be elutriated. ${ }^{16}$ This, together with the sintering of the pores of the limestones, can lead to a reduction of their effective catalytic strength. For this reason the carbonate materials have to be replenished continuously or periodically to maintain stable catalytic activity within the bed, mainly from the viewpoint of tar concentration in the producer gas. 


\subsection{Experimental Goals}

The main aim of this paper is to determine the level of decreasing catalytic activity of dolomitic limestone in a mixture with silica sand during six hours of operation without feeding fresh dolomitic limestone into the fluidized bed. The desired specific output was to estimate a critical time for a periodic replenishment of the dolomitic limestone under standard operation of the fluidized bed. The effect of limestone was analyzed from the viewpoint of production of the main components of the producer gas $\left(\mathrm{H}_{2}, \mathrm{CO}\right.$, $\mathrm{CH}_{4}, \mathrm{CO}_{2}$ and $\mathrm{H}_{2} \mathrm{O}$ ) and from a detailed view of minor organic gases, including compounds classified as tars.

In order to establish a base case without the catalytic effect of limestone, wood chips were first gasified in $770 \mathrm{~mL}(1080 \mathrm{~g})$ of silica sand in a fluidized bed for 5 hours. Then $750 \mathrm{~mL}(1050 \mathrm{~g})$ of dolomitic limestone was added to the fluidized sand bed, to see a direct effect of its addition. Afterwards, the experiment was continued without further intervention for about 6 hours to observe the effect of decreasing catalytic activity of the limestone caused by its attrition and by the sintering of its inner structure.

\section{Materials and Methods}

The experiments were carried out in an electrically-heated spouting FBR (Fig. 1), which is described in detail elsewhere ${ }^{5,6,15,17-19}$. Standard procedures for the preparation of gasifying agent, sampling of the producer gas, on-line analysis by means of nondispersive infrared analysis $\left(\mathrm{CO}, \mathrm{CO}_{2}\right.$ and $\mathrm{CH}_{4}$ content), thermal conductivity analysis $\left(\mathrm{H}_{2}\right)$ and magneto-mechanic analysis $\left(\mathrm{O}_{2}\right.$ content $)$ and more precise off-line analysis of gas composition using gas chromatograph HP 6890 (with flame ionization detector, thermal conductivity detector and mass selective detector) including minor organic gases and tars are also described in these references in detail (the tars are referred in this 
article as compounds with molecular weight higher than benzene). The yield of $\mathrm{H}_{2} \mathrm{O}$ is computed as an average from the $\mathrm{H}$ and $\mathrm{O}$ elemental balance (the difference between the two values is maximally $4 \%$ of the total concentration of $\mathrm{H}_{2} \mathrm{O}$ in the producer gas).

Wood chips (Table 1) were supplied by J. Rettenmaier \& Sohne GmbH, commercially available under the trademark 'Räuchergold HBK 750-2000'. This fuel is used as a standard material in our laboratory and complete analytical details can be found in earlier papers ${ }^{6,15}$. All volume units and other relevant values for the gas are reported at $101.325 \mathrm{kPa}$ and $25^{\circ} \mathrm{C}$ and labelled as $\mathrm{m}_{\mathrm{n}}^{3}$.

\subsection{Experimental Procedure}

Two hours before the fuel dosing started, the electrical heating was turned on and the reactor tube was heated up to $700^{\circ} \mathrm{C}$ with a low flow of nitrogen through it. Then about 30 min before the start of fuel dosing, silica sand was added to the fluidized bed (770 $\mathrm{mL}$ ) through the tube with two valves at the top of the reactor and it was fluidized by nitrogen $\left(2 \mathrm{~m}_{\mathrm{n}}^{3} \mathrm{~h}^{-1}\right.$ through the grate and $1.31 \mathrm{~m}_{\mathrm{n}}{ }^{3} \mathrm{~h}^{-1}$ through the fuel transport line). After reaching $850^{\circ} \mathrm{C}$ in the reactor (measured both in the fluidized bed and in the freeboard region), part of the nitrogen going through the grate was substituted by the gasifying agent $\left(\mathrm{O}_{2}+\mathrm{H}_{2} \mathrm{O}\right.$; according to Table 2) and the fuel feeding started (this point is considered as the beginning of the experiment). After reaching stable conditions (temperature $850^{\circ} \mathrm{C}$, constant gas composition measured by on-line analysis) collection of the first off-line samples started (1h after the beginning of fuel dosing). The process at steady-state conditions was monitored continuously on-line and, every hour, two gas samples and one tar sample were collected for subsequent off-line analysis. 
At $5 \mathrm{~h}$ and $12 \mathrm{~min}$, the raw (uncalcined) dolomitic limestone (1050 g) was added into the sand in the fluidized bed through the tube with two valves at the top of the reactor (the addition lasted approx. $2 \mathrm{~min}$ ). It was left to calcine, which took approx. $40 \mathrm{~min}$. This extended duration was needed for calcination due to the endothermic character of the reaction and due to the limitation of heat supply into the fluidized bed by electrical heating. The end of calcination was determined by the stabilization of temperature at $850{ }^{\circ} \mathrm{C}$ (well above the equilibrium calcination temperature under appropriate $\mathrm{CO}_{2}$ partial pressure) and by the stabilization of $\mathrm{CO}_{2}$ concentration in the gas. The end of calcination was validated after the experiment by performing the elemental $\mathrm{O}$ and $\mathrm{H}$ balance.

At 6:00 of the experimental time, the collection of off-line samples was begun again. The samples for subsequent off-line analyses were collected approximately every hour. After finishing the last sampling (10 $\mathrm{h}$ and $54 \mathrm{~min}$ of the experiment), the heating was turned off, the fuel feeding was interrupted and, at the same time, the gasifying agent was substituted by $\mathrm{N}_{2}$ in order not to burn the char remaining in the fluidized bed. After the temperature of the fluidized bed dropped to $300^{\circ} \mathrm{C}$, the nitrogen flow was turned off and the reactor was left to cool through the night. The next day, all the remaining material was carefully collected for future analyses in order to provide proper overall mass and elemental balances.

\subsection{Materials of the Fluidized Bed}

In Table 3, the properties of the materials supplied to the fluidized bed are summarized. Silica sand is used in fluidized beds for its good mechanical properties and temperature resistance; however, it lacks catalytic qualities. The Italian dolomitic limestone was 
used primarily for its catalytic effect on the gasification process. This limestone is marketed under the trademark 'Franchi'. The elemental composition was measured by X-ray fluorescence spectrometer $9400 \mathrm{XP}$ (THERMO ARL) and the composition is expressed as contents of carbonates $\left(\mathrm{CaCO}_{3}\right.$ and $\left.\mathrm{MgCO}_{3}\right)$ or oxides (other components). The dolomitic limestone was added to the fluidized bed in the carbonate form, but under the conditions in the reactor $\left(850^{\circ} \mathrm{C}\right.$ and partial pressure of $\left.\mathrm{CO}_{2} \sim 13 \mathrm{kPa}\right)$ it releases $\mathrm{CO}_{2}$ to form a porous and catalytically active calcine. The specific fractions of the two materials (silica sand and dolomitic limestone) were carefully selected in order to secure complete fluidization of the mixture on one hand, and to prevent excessive loss of the lime due to attrition and carry-over from the reactor on the other hand. The particles of limestone are supposed to be abraded during the experiment and thus their minimal fluidizing velocity can decrease.

To estimate the level of attrition of the dolomitic limestone in the mixture with silica sand, we used the model developed previously in our lab ${ }^{19}$, which was based on data measured on the same spouting FBR under the same conditions. The results are presented in Fig. 2. The initial volumetric concentration of dolomitic limestone was $49 \%$ and this amount decreased asymptotically to $36 \%$ according to the model. After the end of experiment, a complex mass balance of the system was performed and this value was corrected to $32 \%$ vol. The difference can be caused by using a broader range of particle sizes in this experiment and mainly by the fact that pre-calcined dolomitic limestone was used in the model. However, the asymptotic function of decreasing concentration with time can be assumed to be very similar.

\section{Results and Discussion}


In this experiment, we compared gasification in a fluidized bed of sand (first 5 hours of the experiment) with gasification in a mixture of sand and dolomitic limestone (last 6 hours of the experiment). After the limestone is added, it starts to abrade into smaller particles and continuously is entrained from the reactor (its decreasing concentration in the fluidized bed is estimated in Fig. 2). Moreover, particles remaining in the fluidized bed are presumably deactivated because the micropores are subjected to sintering. Therefore, it was expected, that the catalytic activity of the fluidized bed would decrease substantially during the six hours of operation. On the other hand, the attrited particles with lower diameter will have higher surface, which could enhance their catalytic activity.

\subsection{Major gas components}

The most notable change in the yields of major gases (Fig. 3) occurred after the addition of limestone. The yield of $\mathrm{H}_{2}$ almost doubled, the yield of $\mathrm{H}_{2} \mathrm{O}$ that is produced in the reactor (formed mainly from the moisture of the fuel and by the combustion reactions) dropped to almost zero (i.e., the amount of steam input in gasifying agent is the same as steam output in the producer gas $-1.36 \mathrm{~m}^{3} \mathrm{~h}^{-1}$ ), the yield of $\mathrm{CO}_{2}$ increased notably, the yield of $\mathrm{CO}$ and minor organic species slightly decreased and the yield of $\mathrm{CH}_{4}$ slightly increased. The yield of ethylene decreased (from 0.040 to $0.030 \mathrm{~m}_{\mathrm{n}}^{3} \mathrm{~kg}^{-1}$ ) and the sum of the yields of other minor organic compounds (lighter than toluene) decreased by one half (from 0.018 to $0.0092 \mathrm{~m}_{\mathrm{n}}^{3} \mathrm{~kg}^{-1}$ ). In addition, the conversion of fuel carbon to producer gas increased substantially (Fig. S1 in the supplement) as well as the cold gas efficiency (Fig. S2 in the supplement).

These changes can be explained by the alteration in the rate of the following sequence of reactions: increased rate of the conversion of char (from pyrolysis) and steam (mainly 
from gasifying agent) to $\mathrm{CO}$ and $\mathrm{H}_{2}$ by the heterogeneous water gas reaction (eq. 1), increased rate of conversion of the formed $\mathrm{CO}$ and $\mathrm{H}_{2} \mathrm{O}$ into $\mathrm{CO}_{2}$ and $\mathrm{H}_{2}$ by the watergas shift reaction (eq. 2). Also, the Boudouard reaction (eq. 3) is enhanced both catalytically (lime in the FB) and by the increased partial pressure of $\mathrm{CO}_{2}$ in the system, which increases the consumption of accumulated char. The slightly increased methane yield is probably caused by the decomposition of minor organic compounds by dealkylation reactions (eq. 4) and (eq. 5). This decomposition of organic compounds can be noted in their decreased yields. The yield of ethylene decreases only slightly, because the decomposition is partly compensated by ethylene being the product of the dealkylation reactions. The dealkylation reactions can be expressed in their completed form as steam reforming (eq. 6) and dry reforming (eq. 7); this form is more suitable to describe the decrease in the yield for the sum of minor organic compounds (marked as 'minor species $\mathrm{C}_{\mathrm{x}} \mathrm{H}_{\mathrm{y}}$ ' in Fig. 3).
$\mathrm{C}+\mathrm{H}_{2} \mathrm{O}=\mathrm{CO}+\mathrm{H}_{2}$
$\Delta \mathrm{H}_{\mathrm{r}}^{0}\left(25^{\circ} \mathrm{C}\right)=+131 \mathrm{~kJ} \mathrm{~mol}^{-1}$
(eq. 1)
$\mathrm{CO}+\mathrm{H}_{2} \mathrm{O}=\mathrm{CO}_{2}+\mathrm{H}_{2}$
$\Delta \mathrm{H}_{\mathrm{r}}^{0}\left(25^{\circ} \mathrm{C}\right)=-41 \mathrm{~kJ} \mathrm{~mol}^{-1}$
$\mathrm{C}+\mathrm{CO}_{2}=2 \mathrm{CO}$
$\Delta \mathrm{H}_{\mathrm{r}}^{0}\left(25^{\circ} \mathrm{C}\right)=+173 \mathrm{~kJ} \mathrm{~mol}^{-1}$
(eq. 3)
$\mathrm{C}_{\mathrm{x}} \mathrm{H}_{\mathrm{y}}+\mathrm{H}_{2} \mathrm{O}=\mathrm{C}_{\mathrm{x}-1} \mathrm{H}_{\mathrm{y}-2}+\mathrm{CO}+2 \mathrm{H}_{2} \quad$ Endothermic
$\mathrm{C}_{\mathrm{x}} \mathrm{H}_{\mathrm{y}}+\mathrm{CO}_{2}=\mathrm{C}_{\mathrm{x}-1} \mathrm{H}_{\mathrm{y}-2}+2 \mathrm{CO}+\mathrm{H}_{2} \quad$ Endothermic
$\mathrm{C}_{\mathrm{x}} \mathrm{H}_{\mathrm{y}}+\mathrm{xH}_{2} \mathrm{O}=\mathrm{xCO}+(\mathrm{y} / 2+\mathrm{x}) \mathrm{H}_{2} \quad$ Endothermic
$\mathrm{C}_{\mathrm{x}} \mathrm{H}_{\mathrm{y}}+\mathrm{xCO}_{2}=2 \mathrm{xCO}+(\mathrm{y} / 2) \mathrm{H}_{2} \quad$ Endothermic

The gas composition changed slightly during steady states (Table 4). In the course of gasification with sand in the fluidized bed ( $1 \mathrm{~h}-5 \mathrm{~h}$ of the experiment), the concentration (and yield) of $\mathrm{CO}$ slightly decreased and the concentration of $\mathrm{H}_{2} \mathrm{O}$ slightly increased. This is most probably caused by the accumulation of char (and ash) in the fluidized bed, thus, by a slight change of the reaction conditions. 
In the course of gasification with the mixture of sand and limestone in the fluidized bed (5h-11h of the experiment), the yield of major gases (Fig. 3) changed only slightly despite the decreasing concentration of limestone in the fluidized bed and (expected) decreasing porosity of the lime particles. Namely, the yield of $\mathrm{H}_{2}$ decreased slightly, the yield of $\mathrm{CO}_{2}$ increased moderately, the yield of $\mathrm{CO}$ somewhat increased, the yield of $\mathrm{CH}_{4}$ remained unchanged, the yield of ethylene slightly increased $(0.030,0.031,0.034$, $0.035 \mathrm{~m}_{\mathrm{n}}^{3} \mathrm{~kg}^{-1}$ ) and the sum of the yields of other minor organic compounds (not including tars) slightly increased $\left(0.0092,0.0091,0.010\right.$ and $\left.0.010 \mathrm{~m}_{\mathrm{n}}^{3} \mathrm{~kg}^{-1}\right)$. The yield of steam varied between 0.00 and $0.03 \mathrm{~m}_{\mathrm{n}}^{3} \mathrm{~kg}^{-1}$; this means that an almost equivalent amount of $\mathrm{H}_{2} \mathrm{O}$, which was introduced as the gasifying agent, left the reactor in the form of the producer gas.

Therefore, the fact that the dolomitic limestone was not replenished during the last 6 hours of the experiment did not have any considerable effect on the yields of major gases. For a clearer picture, the composition of raw moist producer gas during the experiment is presented in Table 4 and gas yield and LHVs expressed for different conditions in Table S3 of the supplemental information.

\subsection{Minor Organic Compounds and Tars}

During the first part of the experiment with only silica sand in the fluidized bed (1h5h), benzene showed a slight increase and tar showed a mild decrease in yield (Fig. 4). The decrease of tar (the sum of compounds with molecular weight higher than benzene) was caused mainly by the decrease in the yield of light polyaromatic compounds (2-3 rings, type IV; see Fig. 5). These light changes can be attributed to the accumulating char (acting as a cracking catalyst ${ }^{10}$ ) in the fluidized bed. 
After the addition of limestone, the yield of minor organic compounds as well as the yield of tar decreased substantially, particularly the heavy polyaromatic compounds (type V; Fig. 5 and Fig. 6), which pose the greatest risk in the subsequent handling of the producer gas. This decrease is believed to be mainly caused by catalytically enhanced steam reforming (eq. 6) and dry reforming (eq. 7) and corresponding dealkylation reactions (eq. 4 and 5).

During the final part of the experiment, with the mixture of dolomitic limestone and silica sand $(5 \mathrm{~h}-11 \mathrm{~h})$, the yield of benzene and the sum of 'other gases' remained stable (Fig. 4). The yield of acetylene decreased slightly and the yield of ethane increased in the first two hours after the addition of limestone. The yield of tar continuously increased. This increase consisted mainly (see Fig. 5 and Fig. 6) of the tar compounds of type III (aromatic single-ring compounds) and type IV (light polyaromatic compounds). Unfortunately, the type V tars (heavy polyaromatic compounds), which are the most problematic for further utilization of the gas, showed the largest relative increase (from 0.08 to $0.55 \mathrm{~g} \mathrm{~kg}^{-1}$ ); even though their concentration remained far below the value obtained with only silica sand in the fluidized bed (140 vs. $870 \mathrm{mg} \mathrm{m}_{\mathrm{N}}^{-3}$ ). The increase of type $\mathrm{V}$ tars influenced substantially the increase in the approximate tar dew point (Fig. 6) of the raw producer gas from $103^{\circ} \mathrm{C}$ (at $8: 20$ ) to $178^{\circ} \mathrm{C}$ (at $10: 30$ of the experimental time).

The behavior of minor organic gases (with decreasing yield mainly in the first 2 hours after the addition of the limestone and then remaining stable) suggests that they are influenced mainly by the concentration of dolomitic limestone in the fluidized bed (Fig. 2). The behavior of tar compounds shows, that the level of their decomposition is most 
probably influenced by the deactivation of the lime remaining in the fluidized bed. This deactivation is most probably caused by the sintering of the porous structures of the lime.

In order to extend the explanation of the behavior of the minor organic compounds, the detailed view of the 'other' organic compounds is presented in Fig. S5, the concentrations of organic gases are summarized in Table S4 and the concentrations of individual tar compounds in Table S6 of the supplemental information.

\section{Conclusions}

The addition of limestone into the fluidized bed caused the following changes:

- increased hydrogen content in the gas,

- decreased CO content in the gas,

- increased $\mathrm{H}_{2} / \mathrm{CO}$ ratio,

- increased yield of gas,

- decreased calorific value of gas,

- increased conversion of fixed carbon into the gas,

- increased degree of utilization of steam,

- decreased contents of tar and $\mathrm{C}_{\mathrm{x}} \mathrm{H}_{\mathrm{y}}$ in the gas,

- decreased tar dew point,

- increased cold gas efficiency.

When the dolomitic limestone was not replenished for 6 hours, the bulk composition of the gas did not change remarkably; however, its catalytic activity towards steam and dry reforming of tars continuously decreased. This decrease influenced mainly aromatic single-ring tar compounds. The heavy polyaromatic tar compounds, which are the most problematic tar compounds, were effectively decomposed for the first three hours after the addition of limestone. Their concentration increased notably afterwards, which also caused the increase of the tar dew point of the producer gas. 
The results of this experimental run show that an acceptable level of catalytic activity remains for about $3 \mathrm{~h}$ after introduction of the dolomitic limestone into the FBR, suggesting that periodic rather than continuous replenishment of limestone should be sufficient.

\section{Acknowledgements}

The authors appreciate the help of Professor E.J. Anthony, Cranfield University, UK, and the financial support of the Grant Agency of Czech Republic (GAČR), bilateral grant project of GAČR and National Science Council (NSC) Taiwan, Registr. No. in CR: 14-09692J.

\section{References}

(1) Skoblia, S.; Beno, Z.; Picek, I.; Pohořelý, M. In International Workshop to the project FECUNDUS "New processes for fuel conversion, gas cleaning and $\mathrm{CO}_{2}$ separation if FB and EF gasification of coal, biomass and waste; Prague, Czech Republic, 2013.

(2) Svoboda, K.; Hartman, M.; Trnka, O.; Čermák, J. Chem. Listy 2003, 97, 9-23.

(3) Salomonsson, P. In 5 th International DME Conference; Ann Arbor, MI, 2013.

(4) Rehling, B.; Hofbauer, H.; Rauch, R.; Aichernig, C. Biomass Convers. Biorefinery 2011, 1 (2), 111-119.

(5) Svoboda, K.; Pohořelý, M.; Jeremiáš, M.; Kameníková, P.; Hartman, M.; Skoblia, S.; Šyc, M. Fuel Process. Technol. 2012, 95, 16-26.

(6) Pohořelý, M.; Jeremiáš, M.; Svoboda, K.; Kameníková, P.; Skoblia, S.; Beňo, Z. Fuel 2014, 117, 198-205.

(7) Picek, I.; Skoblia, S.; Beňo, Z.; Pohořelý, M. In 6th International Freiberg Conference on IGCC \& XtL Technologies; Dresden/Radebeul, Germany, 2014.

(8) Devi, L. G.; Ptasinski, K. J.; Janssen, F. J. J. G.; van Paasen, S. V. B.; Bergman, P. C.; Kiel, J. H. Renew. Energy 2005, 30 (4), 565-587.

(9) Torres, W.; Pansare, S. S.; Goodwin, J. G. Catal. Rev. 2007, 49 (4), 407-456.

(10) Devi, L. G.; Ptasinski, K. J.; Janssen, F. J. J. G. Biomass and Bioenergy 2003, 24, 125-140.

(11) Richardson, Y.; Blin, J.; Julbe, A. Prog. Energy Combust. Sci. 2012, 38 (6), 765781. 
(12) Sutton, D.; Kelleher, B.; Ross, J. R. H. Fuel Process. Technol. 2001, 73 (3), 155173.

(13) Abu El-Rub, Z.; Bramer, E. a.; Brem, G. Ind. Eng. Chem. Res. 2004, 43 (22), 6911-6919.

(14) Simell, P. A.; Kurkela, E. A.; Ståhlberg, P.; Hepola, J. O. Catal. Today 1996, 27, $55-62$.

(15) Jeremiáš, M.; Pohořelý, M.; Bode, P.; Skoblia, S.; Beňo, Z.; Svoboda, K. Fuel 2014, 117, 917-925.

(16) Scala, F.; Chirone, R.; Salatino, P. In Fluidized Bed Technologies for Near-Zero Emission Combustion and Gasification; Scala, F., Ed.; Woodhead publishing Limited, 2013; pp 254-315.

(17) Šyc, M.; Pohořelý, M.; Jeremiáš, M.; Vosecký, M.; Kameníková, P.; Skoblia, S.; Svoboda, K.; Punčochář, M. Energy \& Fuels 2011, 25 (5), 2284-2291.

(18) Pohořelý, M.; Svoboda, K.; Hartman, M. Powder Technol. 2004, 142 (1), 1-6.

(19) Hartman, M.; Svoboda, K.; Pohořelý, M.; Šyc, M.; Jeremiáš, M. Chem. Pap. 2013, 67 (2), 164-172.

(20) Thersites, the ECN tar dew point site http://www.thersites.nl. 
Table 1. Proximate and ultimate analysis of wood fuel.

\begin{tabular}{llll} 
& raw & dry & daf \\
\hline Proximate analysis & & & \\
\hline Moisture (\% wt.) & 7.5 & - & - \\
Ash (\% wt.) & 0.9 & 1 & - \\
Volatiles (\% wt.) & 77.6 & 83.8 & 84.7 \\
Fixed carbon (\% wt.) & 14.1 & 15.2 & 15.3 \\
HHV (MJ/kg) & 17.6 & 19.0 & 19.2 \\
LHV (MJ/kg) & 16.2 & 17.7 & 17.9 \\
\hline Ultimate analysis (\% wt.) & & & \\
\hline $\mathrm{C}$ & 43.1 & 46.5 & 47.0 \\
$\mathrm{H}$ & 5.33 & 5.76 & 5.82 \\
$\mathrm{~N}$ & 0.18 & 0.20 & 0.20 \\
$\mathrm{O}$ & 43.0 & 46.5 & 47.0 \\
$\mathrm{~S}$ & 0.017 & 0.018 & 0.019 \\
$\mathrm{Cl}$ & 0.011 & 0.012 & 0.013 \\
\hline
\end{tabular}


Table 2. Experimental conditions (volumetric values relate to $25^{\circ} \mathrm{C}$ and $101.325 \mathrm{kPa}$ )

\begin{tabular}{lc}
\hline Reactor temperature $\left({ }^{\circ} \mathrm{C}\right)$ & $\mathbf{8 5 0} \pm \mathbf{5}$ \\
Dry fuel feeding rate $\left(\mathrm{g} \mathrm{h}^{-1}\right)$ & $\mathbf{1 2 8 0}$ \\
Raw fuel feeding rate $\left(\mathrm{g} \mathrm{h}^{-1}\right)$ & $\mathbf{1 4 2 0}$ \\
\hline Gas inlet & \\
Steam $\left(\mathrm{m}^{3} \mathrm{~h}^{-1}\right)$ & $\mathbf{1 . 3 6}$ \\
$\mathrm{O}_{2}\left(\mathrm{~m}^{3} \mathrm{~h}^{-1}\right)$ & $\mathbf{0 . 2 7}$ \\
Additional $\mathrm{N}_{2}\left(\mathrm{~m}^{3} \mathrm{~h}^{-1}\right)$ & $\mathbf{0 . 3 7}$ \\
$\mathrm{N}_{2}$ pneumatic transport $\left(\mathrm{m}^{3} \mathrm{~h}^{-1}\right)$ & $\mathbf{1 . 3 1}$ \\
\hline Total gas inlet $\left(\mathrm{m}^{3} \mathrm{~h}^{-1}\right)$ & $\mathbf{3 . 3 1}$ \\
\hline Parameters & \\
Equivalence ratio $\left(\mathrm{m}^{3} \mathrm{~m}^{-3}\right)$ & $\mathbf{0 . 2 1}$ \\
$\mathrm{H}_{2} \mathrm{O} / \mathrm{C}\left(\mathrm{mol} \mathrm{mol}^{-1}\right)$ & $\mathbf{1 . 2 2}$ \\
$\mathrm{O} / \mathrm{C}\left(\mathrm{mol} \mathrm{mol}^{-1}\right)$ & $\mathbf{2 . 3 3}$ \\
\hline $\mathrm{H}_{2} \mathrm{O} /$ Fuel $\left(\mathrm{kg} \mathrm{kg}^{-1}\right)$ & $\mathbf{0 . 8 9}$ \\
$\mathrm{O}_{2} /$ Fuel $\left(\mathrm{kg} \mathrm{kg}^{-1}\right)$ & $\mathbf{0 . 2 8}$ \\
\hline
\end{tabular}




\begin{tabular}{|c|c|c|c|}
\hline \multirow{2}{*}{ Materials } & \multirow{2}{*}{ Silica sand } & \multicolumn{2}{|c|}{ Dolomitic limestone } \\
\hline & & raw & calcined \\
\hline Particle size $^{\mathrm{a}}(\mathrm{mm})$ & $0.25-0.50$ & $0.5-1.25$ & $0.5-1.25$ \\
\hline Mean particle size (mm) & 0.375 & 0.875 & 0.875 \\
\hline True solid density ${ }^{\mathrm{b}}\left(\mathrm{kg} \mathrm{m}^{-3}\right)$ & 2530 & 2862 & 2653 \\
\hline Apparent density ${ }^{\mathrm{c}}\left(\mathrm{kg} \mathrm{m}^{-3}\right)$ & 2530 & 2498 & 1150 \\
\hline Particle porosity (vol \%) & 0 & 13 & 64 \\
\hline Bed voidage (vol \%) & 45 & 48 & 35 \\
\hline Loose poured bulk density $\left(\mathrm{kg} \mathrm{m}^{-3}\right)$ & 1394 & 1301 & 743 \\
\hline Specific surface area (BET) $\left(\mathrm{m}^{2} \mathrm{~g}^{-1}\right)$ & - & - & 13.8 \\
\hline Mesopore surface area $\left(\mathrm{m}^{2} \mathrm{~g}^{-1}\right)$ & - & - & 7.6 \\
\hline Micropore volume $\left(\mathrm{mm}^{3} \mathrm{~g}^{-1}\right)$ & - & - & 3.5 \\
\hline Minimum fluidizing velocity* $\left(\mathrm{m} \mathrm{s}^{-1}\right)$ & 0.11 & 0.42 & 0.19 \\
\hline $\begin{array}{l}\text { Minimum fluidizing velocity** }\left(\mathrm{m} \mathrm{s}^{-}\right. \\
\left.{ }^{1}\right)\end{array}$ & 0.05 & 0.25 & 0.10 \\
\hline Complete fluidizing velocity* $\left(\mathrm{m} \mathrm{s}^{-1}\right)$ & 0.18 & 0.64 & 0.32 \\
\hline Complete fluidizing velocity** $\left(\mathrm{m} \mathrm{s}^{-1}\right)$ & 0.09 & 0.48 & 0.20 \\
\hline Loss on ignition $* * *(w t \%)$ & - & 47 & - \\
\hline $\mathrm{CaCO}_{3}(\mathrm{wt} \%)$ & $<0.03$ & 55 & - \\
\hline $\mathrm{MgCO}_{3}(\mathrm{wt} \%)$ & $<0.03$ & 44 & - \\
\hline $\mathrm{SiO}_{2}(\mathrm{wt} \%)$ & 98 & 0.20 & - \\
\hline $\mathrm{Al}_{2} \mathrm{O}_{3}(\mathrm{wt} \%)$ & 1.4 & 0.16 & - \\
\hline
\end{tabular}

Determined by: ${ }^{\mathrm{a}}$ sieving, by helium displacement, ${ }^{\mathrm{c}}$ by mercury displacement

$*$ at $25^{\circ} \mathrm{C}, * *$ at $850^{\circ} \mathrm{C}, * * *$ at $900^{\circ} \mathrm{C}$ and $101.325 \mathrm{kPa}$ 
Table 4 Producer gas composition (raw moist gas, vol. \%)

\begin{tabular}{lccccccc}
\hline Time (h:min) & $1: 13$ & $2: 21$ & $3: 34$ & $6: 00$ & $6: 45$ & $8: 22$ & $10: 30$ \\
\hline $\mathrm{CO}_{2}$ & 8.6 & 8.4 & 8.6 & 12 & 12 & 12 & 12 \\
$\mathrm{H}_{2}$ & 6.8 & 6.9 & 7.1 & 14 & 14 & 14 & 14 \\
$\mathrm{CO}$ & 9.6 & 9.3 & 8.9 & 7.8 & 7.7 & 8.1 & 8 \\
$\mathrm{CH}_{4}$ & 3.3 & 3.3 & 3.2 & 3.3 & 3.2 & 3.4 & 3.4 \\
$\mathrm{~N}_{2}$ & 35 & 35 & 35 & 34 & 34 & 34 & 34 \\
$\mathrm{H}_{2} \mathrm{O}$ & 35 & 36 & 36 & 28 & 28 & 27 & 28 \\
\hline Ethylene & 1.1 & 1.1 & 1.1 & 0.77 & 0.80 & 0.89 & 0.91 \\
other $\mathrm{C}_{\mathrm{x}} \mathrm{H}_{\mathrm{y}}$ & 0.47 & 0.48 & 0.48 & 0.24 & 0.24 & 0.26 & 0.26 \\
\hline
\end{tabular}




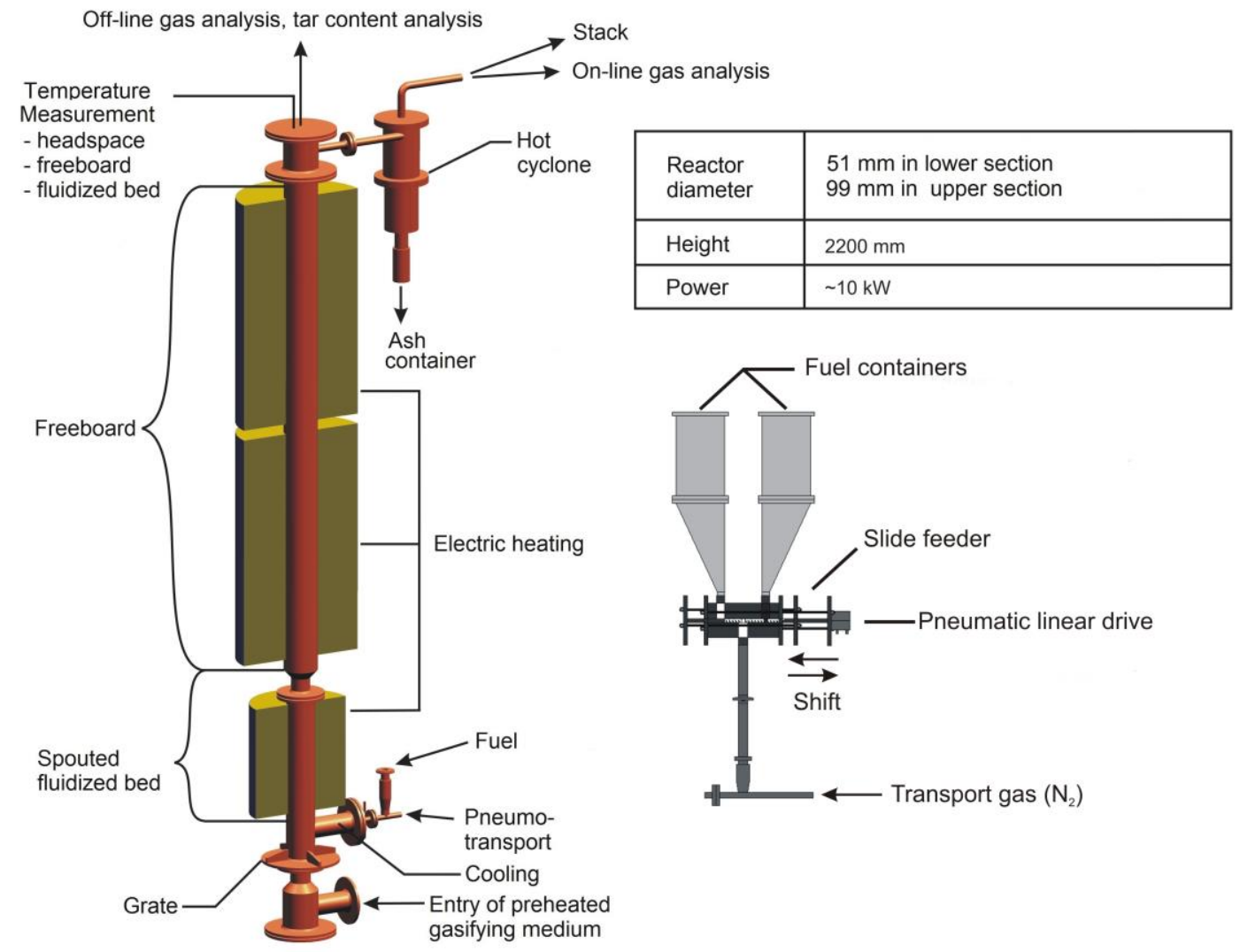

Fig. 1. Experimental fluidized-bed reactor (right) and pneumatic fuel feeder (left) 


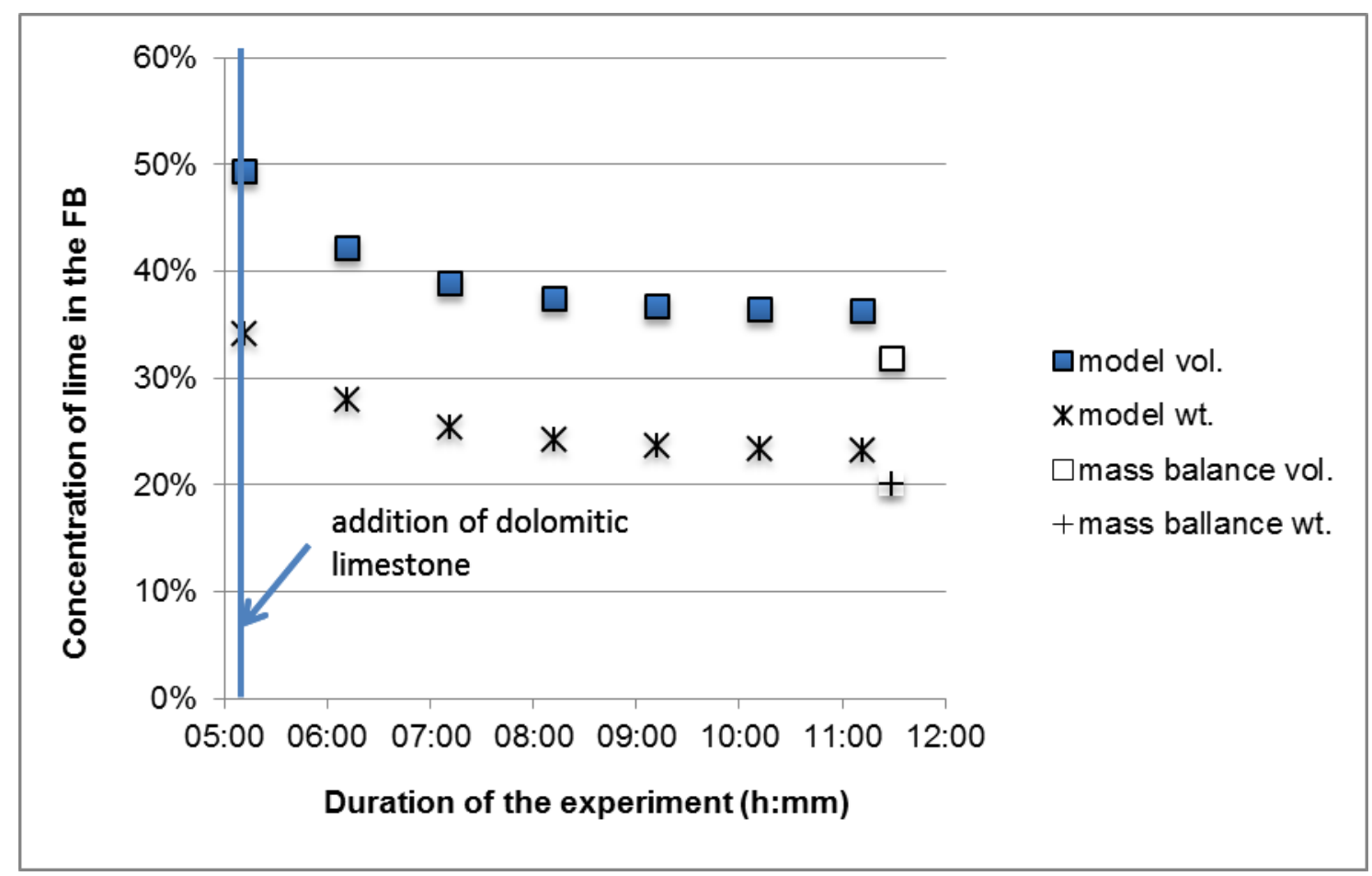

Fig. 2. Concentration (volumetric and by mass) of the lime (calcined dolomitic limestone) in fluidized bed according to a previously developed model ${ }^{19}$ compared with the output values of mass balance after the experiment. 


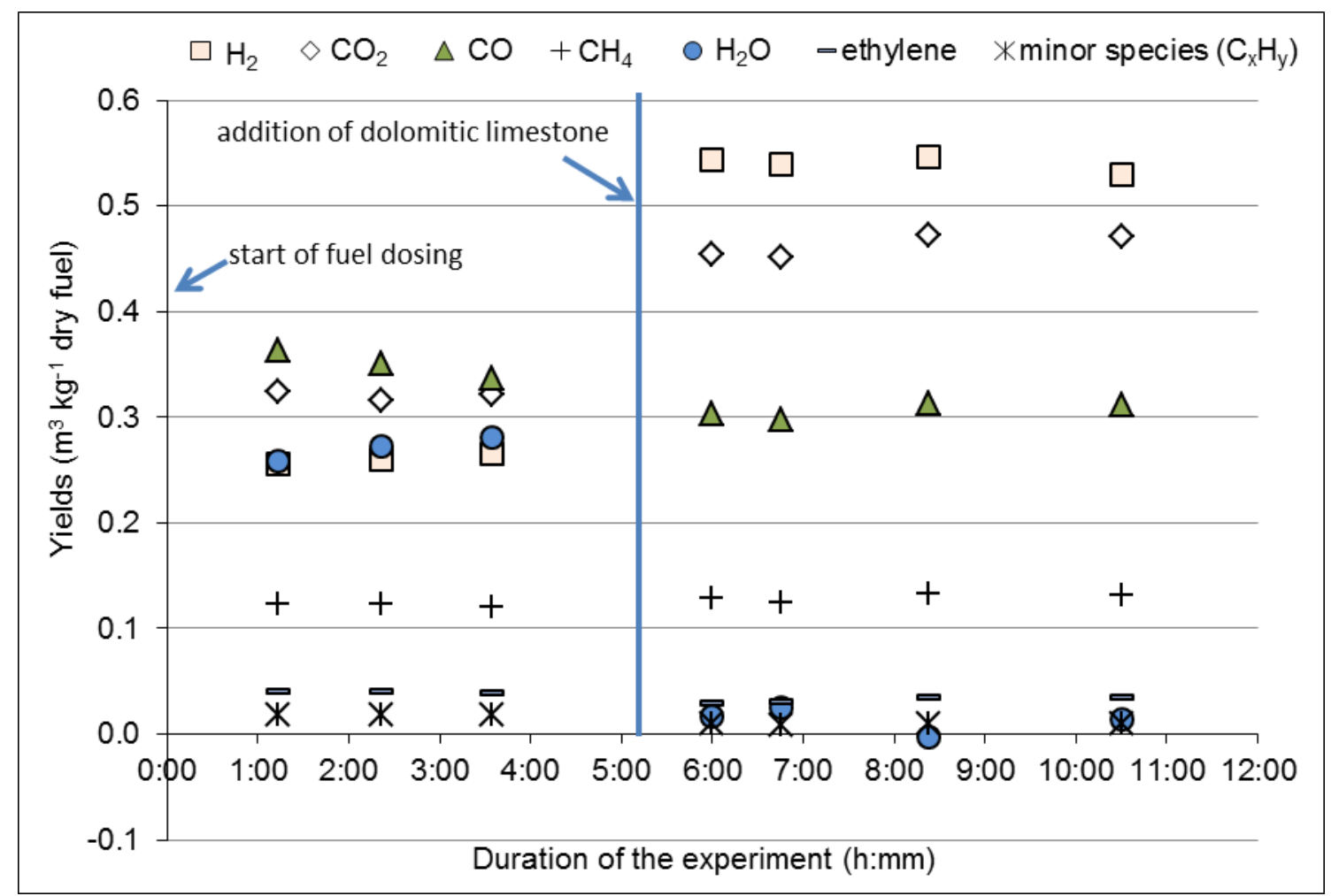

Fig. 3. The yield of major gases

(The $\mathrm{H}_{2} \mathrm{O}$ yield concerns only steam formed during the gasification process; it does not include the steam coming into the reactor as part of the gasifying agent mixture $\left(1.36 \mathrm{~m}_{\mathrm{n}}^{3} \mathrm{~h}^{-1}=1.06 \mathrm{~m}_{\mathrm{n}}{ }^{3} \mathrm{~kg}^{-1}\right.$ of dry fuel); for real concentrations of $\mathrm{H}_{2} \mathrm{O}$ in the gas, see Table 4) 


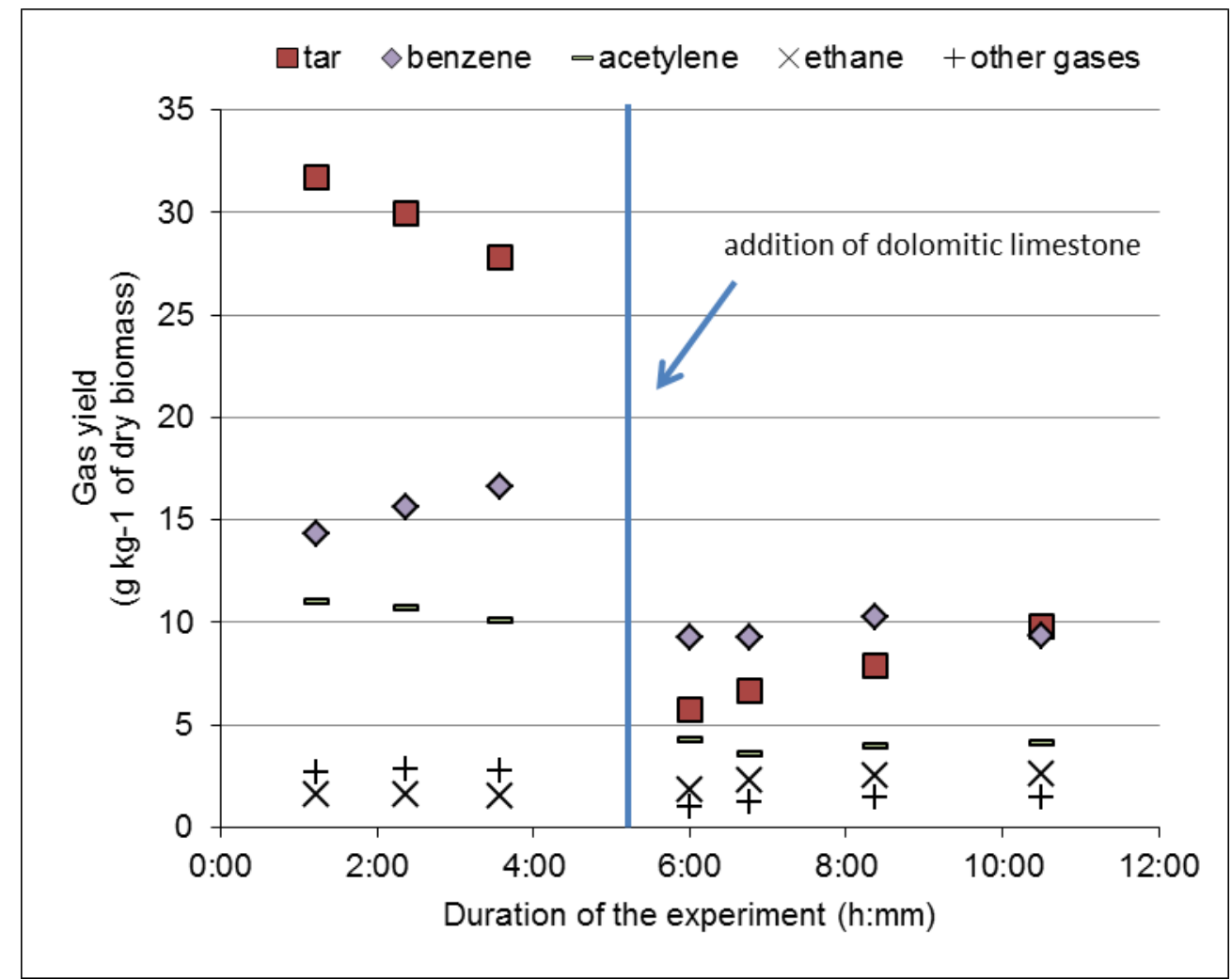

Fig. 4. The yield of minor organic compounds (GC-FID) and tars (GC-MS) 


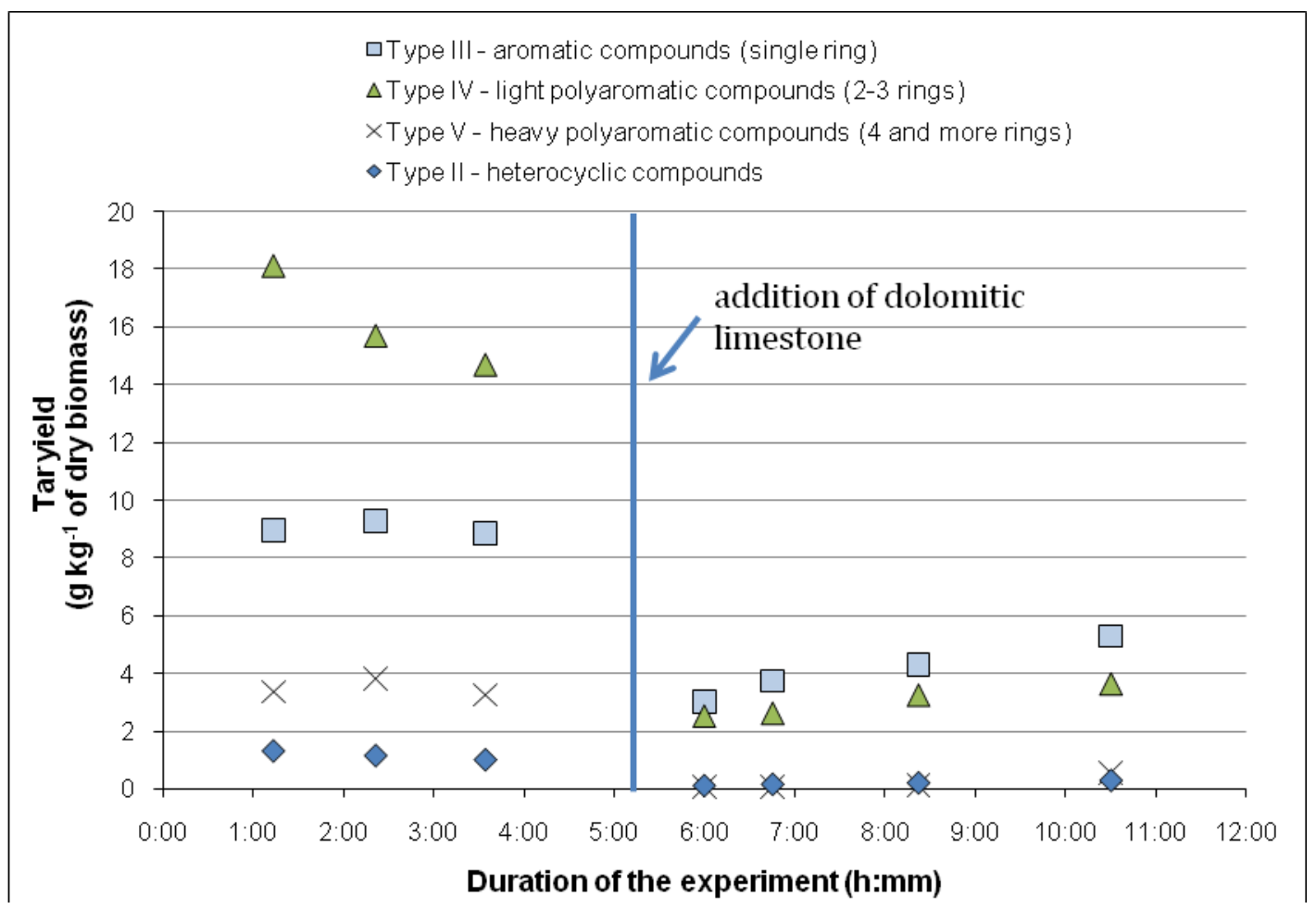

Fig. 5. The yield of tar compounds classified into five classes according to 'Thersites' 20. 


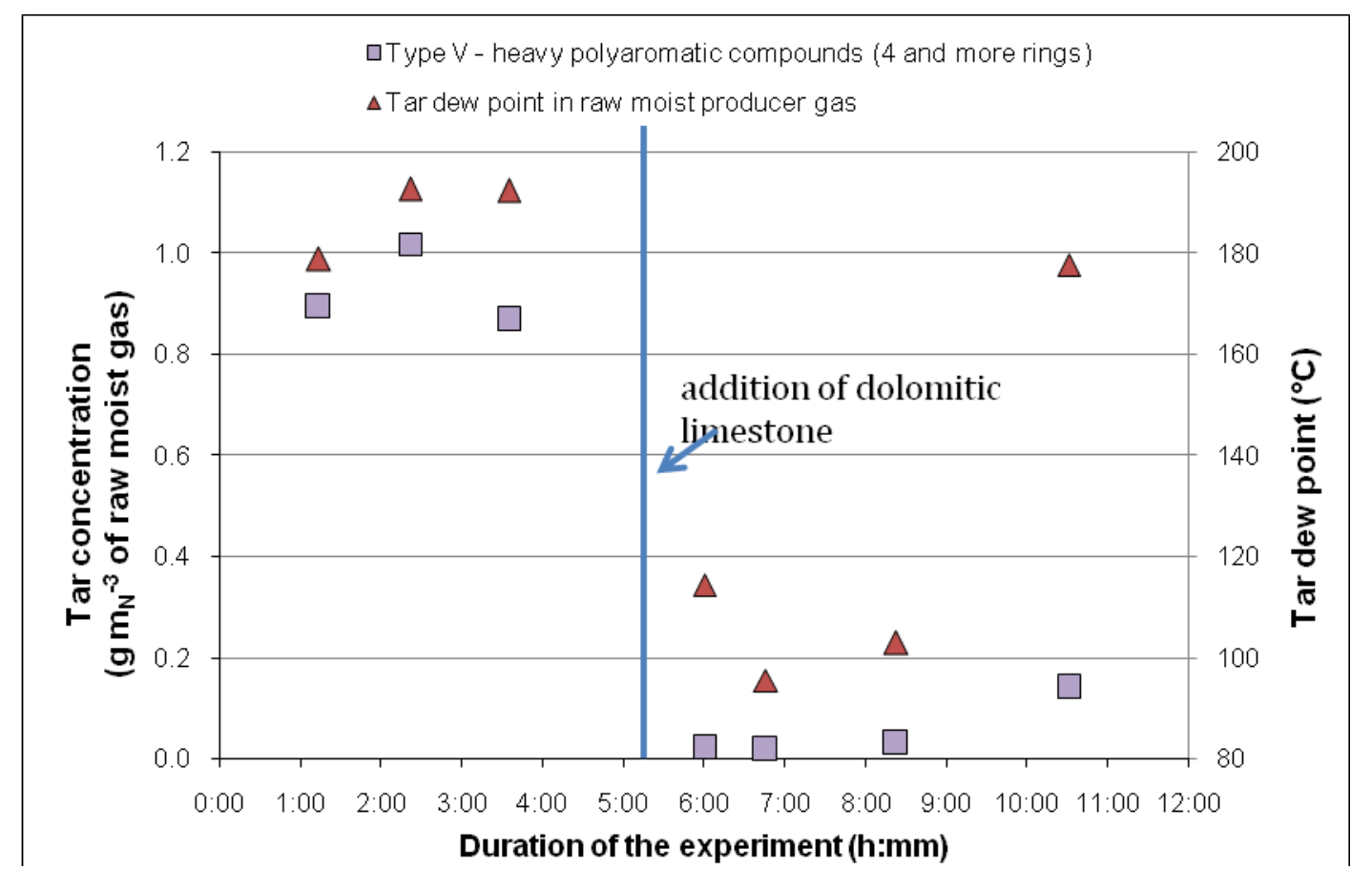

Fig. 6. Approximate tar dew point (calculated by the extended model by 'Thersites' ${ }^{20}$ ) and a detailed view of the type $\mathrm{V}$ tar yield 